Gepubliceerd in Mens en Maatschappij, 2010, 85(3).

\title{
Het is tijd voor een quotum
}

In Nederland blijft het percentage vrouwen aan de top bedroevend laag. Intentieverklaringen, handvesten, mentorprojecten, codes, taskforces, ambassadeursnetwerken en allerlei bewustwordingstrajecten hebben daar geen substantiële of duurzame verandering in gebracht.

Universiteiten, de overheid, KNAW en NWO hebben de afgelopen jaren extra geld vrijgemaakt voor stimuleringsbeleid voor vrouwelijke wetenschappers. Desondanks is het tempo van de doorstroom van vrouwen naar hogere academische functies zeer laag. Sinds 2003 is het percentage vrouwelijke hoogleraren met gemiddeld een half procent per jaar toegenomen. Volgens de Monitor Vrouwelijke Hoogleraren is op dit moment twaalf procent van de hoogleraren een vrouw. In het Lissabonakkoord is afgesproken dat in 2010 een kwart van de hoogleraren vrouw zou moeten zijn. Als het percentage vrouwelijke hoogleraren in het huidige tempo blijft stijgen, voldoet Nederland pas in 2030 aan die norm.

In het bedrijfsleven zijn vergelijkbare voorbeelden te vinden. De ING reserveert een deel van de bonus van iedere bedrijfseenheid voor wat in het jargon "diversiteitsdoelen" heten. Het bedrijf slaagde erin om tussen 2003 en 2007 het percentage vrouwen in topmanagement posities wereldwijd van acht naar tien procent te laten stijgen. Als deze trend zich in hetzelfde tempo doorzet, dan duurt het tot 2035 voordat een aandeel van dertig procent vrouwen in managementfuncties wordt bereikt. Pas bij dat percentage van vertegenwoordiging wordt volgens de Amerikaanse organisatiesociologe Kanter een minderheid niet langer als uitzondering beschouwd maar als "gewoon".

Een van de meest recente pogingen om vrouwen sneller tot de top te laten doordringen betreft het amendement streefcijfers, dat in december 2009 met een ruime meerderheid in de Tweede Kamer is aangenomen. Volgens dit amendement moeten alle beursgenoteerde ondernemingen en alle ondernemingen met meer dan 250 werknemers streven naar minimaal dertig procent vrouwen in Raden van Commissarissen en minimaal dertig procent vrouwen in Raden van Bestuur. Haalt een onderneming in 2016 de streefcijfers niet, dan is een verklaring verschuldigd en moet een verbeterplan worden overlegd. Helaas gaat dit amendement volledig voorbij aan het gebrek aan diversiteit bij de overheid en publieke instellingen. Gelukkig is er het charter Talent naar de Top, dat tot stand is gekomen in een nauwe samenwerking tussen de overheid en het bedrijfsleven. Door ondertekening van het charter zeggen werkgevers in de publieke en private sector toe om concrete maatregelen te nemen om meer vrouwelijk talent aan boord te krijgen, te behouden en te benoemen. Wergevers rapporteren jaarlijks over hoe zij scoren ten opzichte van door henzelf vastgestelde diversiteitsdoelstelligen.

De hiervoor beschreven initiatieven zijn prijzenswaardig, maar niet genoeg. Ze zijn te vrijblijvend en de veranderingen gaan te langzaam. Het wordt tijd voor meer ingrijpende 
maatregelen zoals een quotum. De weestand tegen een opgelegd quotum is echter groot en mijns inziens onterecht.

Een van de tegenargumenten is dat multinationals Nederland als vestigingsland zullen vermijden als een quotum wordt ingevoerd. Interessant is dat diversiteit juist een bewezen succesfactor is. Uit onderzoek van McKinsey \& Company in 2007 onder ruim 100 bedrijven wereldwijd komt naar voren dat bedrijven met minimaal dertig procent vrouwen in senior management hoger scoren op organisatiecriteria zoals leiderschap, efficiëntie, motivatie en integriteit. Deze criteria op hun beurt hangen samen met hogere productiviteit. Een onderzoek uit 2008 van McKinsey \& Company toont aan dat de 89 Europese bedrijven met het hoogste aandeel vrouwen in management beter presteren dan het gemiddelde voor hun sector op vermogensrendement, aandelenprijs en winst. Uiteraard mag op basis van samenhangen geen conclusie worden getrokken over de richting van causaliteit. Niet kan worden uitgesloten dat succesvolle bedrijven beter in staat zijn om topvrouwen aan te trekken en te behouden. Op basis van longitudinale gegevens over 1500 Amerikaanse bedrijven verzameld tussen 1992 en 2006 concluderen de economen Deszǒ en Ross dat een sterkere vertegenwoordiging van vrouwen leidt tot en niet alleen het gevolg is van betere bedrijfsresultaten.

Een ander veelgehoord tegenargument is dat Nederlandse vrouwen de ambities missen om door te dringen tot de top. Immers, volgens het in 2009 verschenen rapport Deeltijd (g)een probleem van het Sociaal Cultureel Planbureau zijn de meeste vrouwen heel tevreden met hun kleine deeltijdbaan. Terecht stelt de Nijmeegse econome Sent in $M e$ Judice hier de vraag: Welke vrouw zou er ook meer uren willen gaan werken als dit tegen institutionele en culturele belemmeringen oploopt? De belemmeringen om tot een hogere arbeidsparticipatie te komen liggen niet bij Nederlandse vrouwen maar bij een samenleving die formeel en informeel nog sterk is verankerd in het kostwinnerschap.

Een tegenargument dat vooral door vrouwen naar voren wordt gebracht is dat een quotum slecht is voor de beeldvorming. Vrouwen zouden het stempel krijgen dat ze de functie alleen aan hun vrouw-zijn te danken hebben. Dit bezwaar verdient serieuze aandacht. Benadrukt dient te worden dat een voorkeursbeleid gericht is op het bestrijden van bestaande structurele ongelijkheid en dat vrouwen uitsluitend voorrang krijgen bij gelijke geschiktheid. Ook moet worden benadrukt dat een quotum gericht is op een betere benutting van vrouwelijk talent in hogere posities.

Organisaties met veel vrouwen aan de top hebben een competetief voordeel. Ze presteren niet alleen beter, maar ze beschikken over een bredere talentenpoel in tijden van arbeidsschaarste. Het niet kunnen behouden van vrouwelijk talent betekent het verlies van investering in menselijk kapitaal. Een quotum voor vrouwen in de top is niet alleen gunstig vanuit het oogpunt van rechtvaardigheid maar ook vanuit een zakelijk perspectief.

Pearl A. Dykstra 